\title{
Use of remote sensing and GIS in mapping the environmental sensitivity areas for desertification of Egyptian territory
}

\section{A. Gad and I. Lotfy}

National Authority for Remote Sensing and Space Sciences, Egypt

Received: 25 January 2008 - Accepted: 6 May 2008 - Published: 4 June 2008

Correspondence to: A. Gad (abdallagad@gmail.com)

Published by Copernicus Publications on behalf of the European Geosciences Union.

Title Page

Abstract

Introduction

Conclusions

References

Tables

Figures

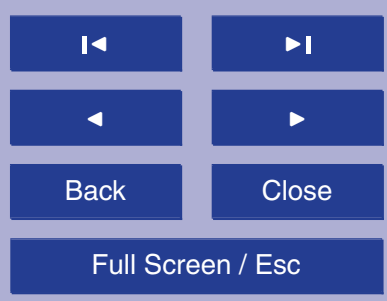

Printer-friendly Version

Interactive Discussion 


\section{Abstract}

Desertification is defined in the first art of the convention to combat desertification as "land degradation in arid, semiarid and dry sub-humid areas resulting from climatic variations and human activities". Its consequence include a set of important processes factor of land use performance in such ecosystem. Desertification indicators or the groups of associated indicators should be focused on a single process. They should be based on available reliable information sources, including remotely sensed images, topographic data (maps or DEM'S), climate, soils and geological data. The current whole territory of Egypt at a scale of 1:1000 000 .

ETM satellite images, geologic and soil maps were used as main sources for calculating the index of Environmental Sensitivity Areas (ESAI) for desertification. The algorism is adopted from MEDALLUS methodology as follows;

$$
\mathrm{ESAl}=(\mathrm{SQI} * \mathrm{CQI} * \mathrm{VQI})^{1 / 3}
$$

Where SQI is the soil quality index, CQI is the climate quality index and VQI is the vegetation quality index. The SQI is based on rating the parent material, slope, soil texture, and soil depth. The VQI is computed on bases of rating three categories (i.e. erosion protection, drought resistance and plant cover). The CQI is based on the aridity index, derived from values of annual rainfall and potential evapotranspiration. Arc-GIS 9 software was used for the computation and sensitivity maps production.

The results show that the soil of the Nile Valley are characterized by a moderate SQI, however the those in the interference zone are low soil quality indexed. The dense vegetation of the valley has raised its VQI to be good, however coastal areas which are active in arid and semi arid environment, where water is the main limiting

3, 41-85, 2008

Desertification sensitivity

A. Gad and I. Lotfy

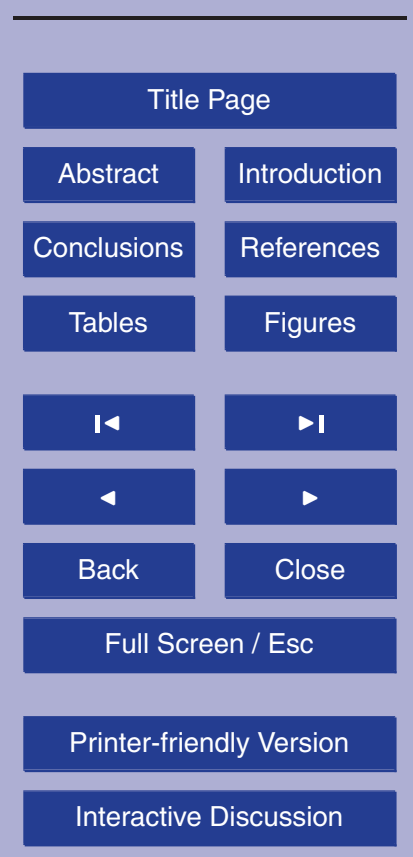
show that $86.1 \%$ of Egyptian territory is classified as very sensitive areas, while $4.3 \%$ as Moderately sensitive, and $9.6 \%$ as sensitive. 
It can be concluded that implementing the maps of sensitivity to desertification is rather useful in the arid and semi arid areas as they give more likely quantitative trend for frequency of sensitive areas. The integration of different factors contributing to desertification sensitivity may lead to plan a successful combating. The usage of space 5 data and GIS proved to be suitable tools to rely estimation and to fulfill the needed large computational requirements. They are also useful in visualizing the sensitivity situation of different desertification parameters.

\section{Introduction}

Desertification is the consequence of a set of important processes, which are active 10 in arid and semi-arid environment, where water is the main limiting factor of land use performance in ecosystems (Batterbury and Warren, 2001). In the context of the EC MEDLUS (Mediterranean Desertification and Land Use, a distinction has been made between degradation processes in European Mediterranean environments and the more arid areas. Physical loss of soil by water erosion, and associated loss of soil 15 nutrient status are identified as the dominant problems in the European Mediterranean region. However, Wind erosion and salinisation problems are most often in the arid Mediterranean areas (Glantz, 1977; Quintanilla, 1981; Zonn, 1981).

Environmental systems are generally in a state of dynamic equilibrium with external driving forces. Small changes in the driving forces, such as climate or imposed land use tend to be accommodated partially by a small change in the equilibrium and partially by being absorbed or buffered by the system. Desertification of an area will proceed if certain land components are brought beyond specific threshold, beyond which further change produces irreversible change (Tucker et al., 1991; Nicholson et al., 1998). For example, climate change cannot bring a piece of land to a desertified state by itself,
3, 41-85, 2008

Desertification sensitivity

A. Gad and I. Lotfy

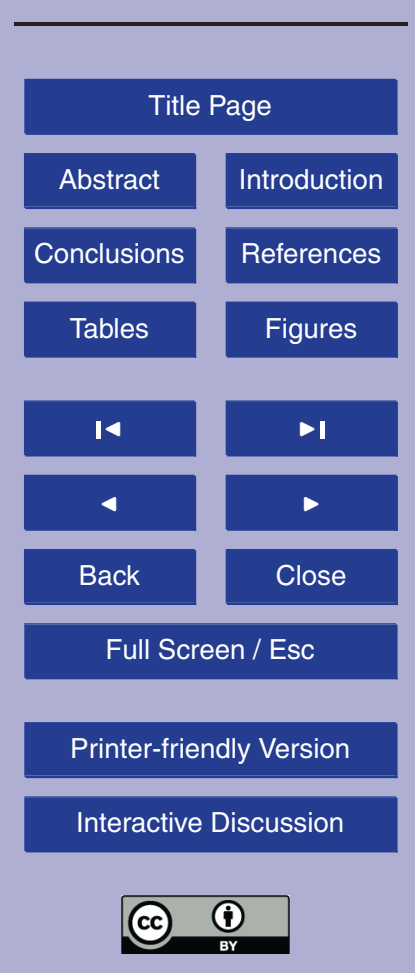


to desertification for various reasons. For example there are areas presenting high sensitivity to low rainfall and extreme events due to low vegetation cover, low resistance of vegetation to drought, steep slopes and highly erodable parent material (Ferrara et al., 1999).

$5 \quad$ Land degradation processes involve two interlocking, complex systems: the natural ecosystem and the human social system (WMO, 2005). Natural forces, through periodic stresses of extreme and persistent climatic events, and human use and abuse of sensitive and vulnerable dry land ecosystems, often act in unison, creating feedback processes. Interactions between the two systems determine the severity of the 10 degradation process. Inclusion of climate, vegetation, and land use into desertification assessment is reviewed by Gad (2008). The Universal Soil Loss Equation (USLE) was developed in the mid-1960s for understanding soil erosion for agricultural applications. In 1985, it was updated and renamed the Revised Universal Soil Loss Equation (RUSLE) to incorporate the large amount of information that had accumulated since 15 the original equation was developed and to address land use applications besides agriculture. The RUSLE is derived from the theory of soil erosion and from more than 10000 plotyears of data from natural rainfall plots and numerous rainfall simulations. The RUSLE states that:

$A=R K L S C P$

20 Where $A$ is the soil loss per year (t/ha/year); $R$ represents the rainfall-runoff erosivity factor; $K$ is the soil erodibilty factor; $L$ represents the slope length; $S$ is the slope steepness; $C$ represents the cover management, and $P$ denotes the supporting practices factor. These factors illustrate the interaction of various climatic, geological, and human factors, and that smart land management practices can minimize soil erosion 25 and even land degradation.

Desertification indicators are those, which indicate the potential risk of desertification while there still time and scope for remedial action. Regional indicators should be based on available international source materials, including remotely sensed images, topographic data (maps or DEM's), climate, soil and geologic data (Woodcock

$3,41-85,2008$

Desertification sensitivity

A. Gad and I. Lotfy

Title Page

Abstract Introduction

Conclusions References

Tables Figures

\begin{tabular}{|c|c|}
\hline I & \multicolumn{1}{|c|}{} \\
\hline Back & Close \\
\hline Full Screen / Esc \\
\hline
\end{tabular}

Printer-friendly Version

Interactive Discussion

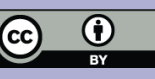


et al., 1994; Pax-Lenney et al., 1996). At the scale ranging 1:25000 to 1:1000000 the impact of socio-economic drivers is expressed mainly through pattern of land use. Each regional indicator or group of associated indicators should be focused on a single desertification process. The various types of ESA's to desertification can be distin5 guished and mapped by using certain key indicators for assessing the land capability to withstand further degradation, or the land suitability for supporting specific types of land use. The key indicators for defining ESA's to desertification, which can be used at regional or national level, can be divided into four broad categories defining the qualities of soil, climate, vegetation, and land management (Kosmas et al., 1999). This 10 approach includes parameters, which can easily be found in existing soil, vegetation and climate reports.

\section{Methodology}

The identification of sensitive areas is based on the hypotheses of MEDALUS project model (Giordano et al., 2008). The model applies a geometrical average of some 15 quality indexes, in order to provide sensitivity diagnosis. It assumes that each index has only a limited capacity to influence the final value of ESA index and only when several parameters have a high score, an area can be assigned to high sensitivity class.

The following three quality indices were computed;

20 - Soil Quality Index (SQI),

- Vegetation Quality Index (VQI)

- Climatic Quality Index (CQI)

The methodology is based on classification of each quality index obtained as geometric mean of available environmental and anthropogenic parameters. The available parameters are quantified in relation to their influence on the desertification process
3, 41-85, 2008

\section{Desertification} sensitivity

A. Gad and I. Lotfy

Title Page

Abstract Introduction

Conclusions References

Tables

Figures

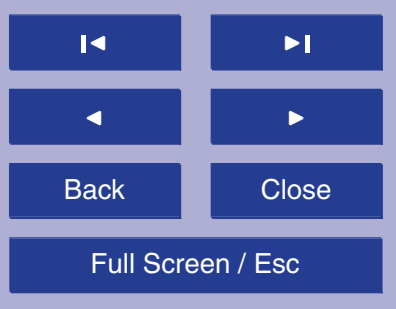

Printer-friendly Version

Interactive Discussion

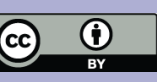


assigning score to each. The scores assigned to different parameters range between 1 (best value) and 2 (worst value). The final overall ESA index is obtained as a geometrical average of the quality indexes (E.C, 1999).

Figure 1 demonstrates the main flow chart of concepts and studied steps performed 5 in the current study. The main input data for calculating these indices include a mosaic of LANDSAT ETM image, geologic map of Egypt, produced by CONOCO, 1990, climatic data derived from the Ministry of Agriculture. An image processing system (i.e. ERDAS IMAGINE 8.3) and a GIS system (i.e. Arc GIS 9) were the main tools in indices computations and ESA's mapping.

\subsection{Mapping Soil Quality Index (SQI)}

Soil is the dominant factor of the terrestrial ecosystems in the arid and semi arid and dry zones, particularly through its effect on biomass production. Soil quality indicators for mapping ESA's can be related to water availability and erosion resistance (Briggs et al., 1992; Basso et al., 1998). A number of four soil parameters were considered at the current investigation (i.e. parent material, soil texture, soil depth and slope gradient). Weighting factors were assigned to each category of the considered parameters, on basis of OSS, 2004, which were adapted from Medalus project methodology (European Commission, 1999). Tables 1 to 4 demonstrate the assigned indexes for different categories of each parameter. The soil Quality Index (SQI) was calculated on basis of

SQI $=\left(I_{p} * I_{t} * I_{d} * I_{s}\right)^{1 / 4}$

$I_{p}$ index of parent material, $I_{t}$ index of soil texture, $I_{d}$ index of soil depth, $I_{s}$ index of slope gradient).
3, 41-85, 2008

Desertification sensitivity

A. Gad and I. Lotfy

Title Page

Abstract Introduction

Conclusions

References

Tables

Figures

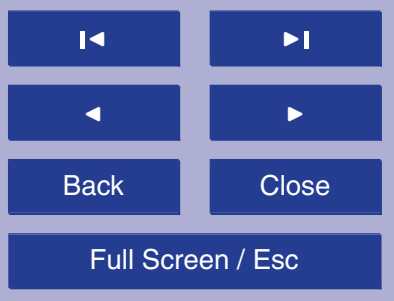

Printer-friendly Version

Interactive Discussion 
Vegetation quality, according to Basso et al. (2000) is assessed in terms of three aspects (i.e. erosion protection to the soils, drought resistance and plant cover). The TM satellite images mosaic covering Egypt (Fig. 2) is the main material used to map veg5 etation and plant cover classes. Adapted rating values for each of erosion protection, drought resistance and vegetal cover classes were adapted on basis of OSS (2004) as shown in Table 6. Vegetation Quality Index was calculated according the following equation, while VQI was classified on basis of the ranges indicated in Table 7.

VQI $=\left(I_{E p} * I_{D r} * I_{V C}\right)^{1 / 3}$

10 Where: $I_{E p}$ index of erosion protection, $I_{D r}$ index of drought resistance and $I_{V C}$ index of vegetation cover).

Ranking of different elements is based upon the magnitude of vegetation fundamental role in erosion protection, drought resistance and soil capacity protection. The perennial cultivation provides a very high capacity to reduce the kinetic energy caused 15 by the impact of soil erosion driving forces. Furthermore, the plant root system increases the stability of the soil, thus a value of (1) was assigned to rank each of $I_{E p}$, $I_{D r}$, and $I_{V c}$. Gradual relative lower capacity are provided by other vegetation classes (e.g. Halophytes, orchards, Saharan vegetation, etc.), thus relatively higher values are assigned for different sensitivity indices.

\subsection{Mapping Climatic quality index (CQI)}

The aim of the climatic quality index (CQI) in the current investigation is to assess the water availability to vegetation. Climatic quality is assessed by using parameters that influence water availability to plants such as the amount of rainfall, air temperature and aridity, as well as climate hazards, which might inhibit plant growth (Thornes,
3, 41-85, 2008

Desertification sensitivity

A. Gad and I. Lotfy

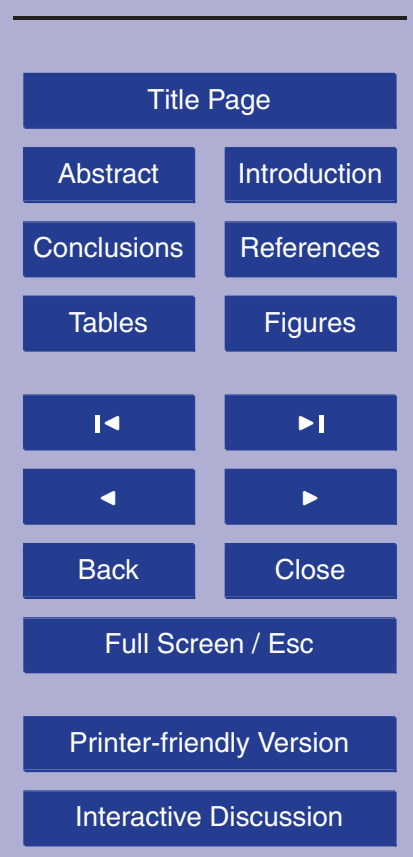

Interactive Discussion

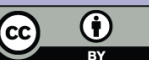


to OSS (2003). The Climate quality index is evaluated through the Aridity Index (AI), using the methodology developed by the Applied Meteorology Foundation "FMA" (René Gommes et al., 2007) in accordance with the following formula In the current study, rainfall and evapotranspiration data on a number of 33 metrological stations, published 5 in the Monthly weather report (The Arab Republic of Egypt ARE, 1979), were used to calculate the CQI as follows;

$\mathrm{CQI}=P / \mathrm{PET}$

Where: $P$ is average annual precipitation and ETP is average annual Potential EvapoTanspiration

\subsection{Mapping Environmentally Sensitive Areas (ESA's) to Desertification}

ArcGIS9 software was used to map ESA's to Desertification (Kosmas et al, 1999) by integrating all data concerning the soil, vegetation and climate. Different quality indices were calculated and displayed as GIS ready maps from which class areas were deduced. The Desertification Sensitivity Index (DSI) was calculated in the polygonal attribute tables linked with the geographic coverage according to the following equation;

$\mathrm{DSI}=(\mathrm{SQI} * \mathrm{VQI} * \mathrm{CQI})^{1 / 3}$

\section{Results and discussions}

\subsection{Soil Quality Index (SQI)}

The geologic map was used to deduce the nature of parent material, which is demonstrated in Figs. 3 and 4 . Table 10 summarizes the areas of various parent materials classes, as deduced from the GIS system.

The results show that $48 \%$ of the territory is originated from soft to friable parent material (i.e. friable sand, calcareous clay and colluviums materials). The coherent

$3,41-85,2008$

Desertification sensitivity

A. Gad and I. Lotfy

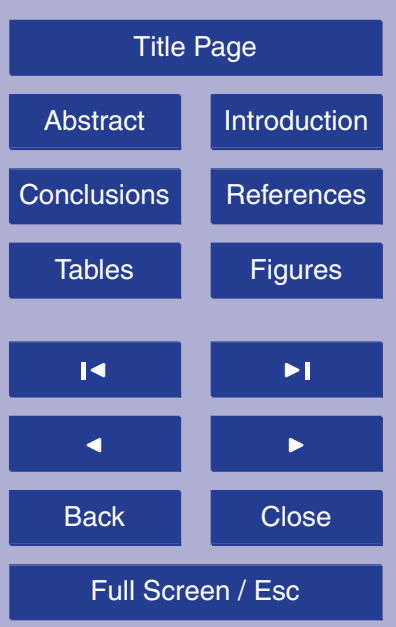

Printer-friendly Version

Interactive Discussion

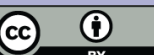


parent materials are limited in the Red Sea Mountains and southern Sinai, as these regions are mostly coherent hard crystalline Rockland. The soil depth (Fig. 5) was also evaluated on basis of both geologic map (CONCO, 1989) and soil map of Egypt (ASRT, 1982).

5 Table 11 shows that the soils characterized by a very shallow soil depth represent $44.2 \%$ of Egyptian territory. Those soils characterized by deep and very deep soils do not exceed more than $30 \%$ of the whole territory, located mainly in the Nile Valley and Delta and areas of sandy plains.

The soil texture was assessed on basis of the geomorphology, deduced from the 10 ETM satellite mosaic. Table 12 and Fig. 6 show that the most sensitive coarse textured soils amount $81.5 \%$ of whole territory. The alluvial Nile Valley is exhibited by average textured soils, covering $8.25 \%$ of all soils. The colluviums (16.7\%), brought by the alluvial fans and ravines, at the desert fringes, are exhibited by very light to average textured soils. The wadi soils are characterized by fine to average textured soils, cover15 ing $1.7 \%$ of all soils. The slope gradient (Fig. 7 and Table 13) was classified, on basis of topographic maps and digital elevation model (DEM). Calculating the soil quality index (Table 14 and Fig. 8) reveals that the majority of Egyptian soils (64.84\%) are characterized by very low soil quality. The soils of the Nile Valley $(21 \%)$ are characterized by moderate quality due to its capability to sustain soil structure and moisture. Those soils

\subsection{Vegetation Quality Index (VQI)}

Hybrid classification of ETM images (Fig. 9) resulted in identifying a number of four vegetation classes. Each of these classes was given a score evaluating vegetation cover, erosion protection and drought resistance (Table 15).

25 Calculating the vegetation quality index, on basis of the previous parameters (Table 16 and Fig. 10) reveal that the $94.29 \%$ of the vegetation cover is very weak and sensitive to desertification. The good vegetation index class, which may resist desertification, represents only $3.51 \%$ of the vegetation cover.

$3,41-85,2008$

Desertification sensitivity

A. Gad and I. Lotfy

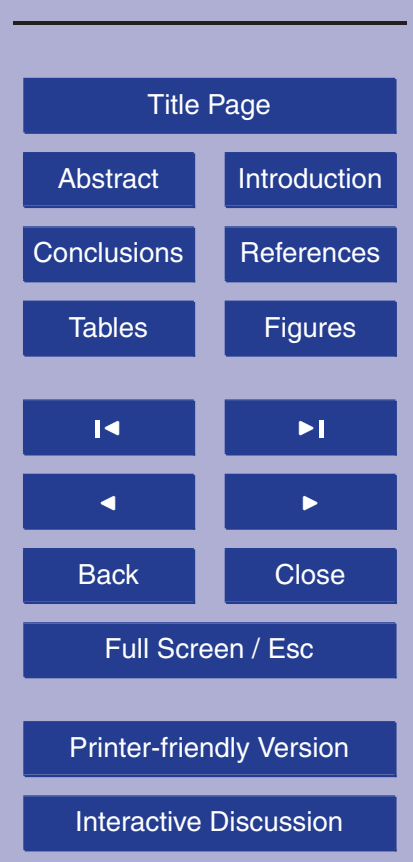

Interactive Discussion

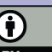




\subsection{Climate Quality Index (CQI)}

Climatic data (i.e. rainfall and evapo-transpiration) interpolation resulted in obtaining values for both parameters (Figs. 11 and 12). The climatic sensitivity index was calculated and stored in a GIS ready map (Fig. 13). Most rainfed areas are located in 5 the northern coastal region and don't exceed $200 \mathrm{~mm}$. annually. The average annual rainfall drops down to almost zero, at less than $50-150 \mathrm{~km}$ distance south of the Mediterranean coast. The average annual potential evapo-transpiration is relatively high in the whole country, however increases southwards. Table 17 shows the areas of climatic quality index classes. The hyper arid climatic conditions characterize $89.3 \%$ of

\subsection{Environmentally Sensitive Areas (ESA's) to Desertification}

The three previous indices were driven together for the assessment of the environmentally sensitive areas (ESA's) to desertification, on basis of the calculated Desertification Sensitivity Index (DSI). Figure 14 shows the distribution of ESA's, while Table 18 demonstrates their areas. It is clear that most of the Egyptian territories are very sensitive and sensitive to desertification; these classes exhibit 74.39 and $20.27 \%$ of the whole territory respectively. The Nile Valley region is classified as moderately sensitive area, as its moderate quality soils are protected by good quality vegetation. The oases and the interference zone between the desert area and the Nile Valley are vulnerable

\section{Conclusions and recommendations}

It can be concluded that the assessment of desertification sensitivity is rather important to plane combating actions and to improve the employment of natural resources. It can be realized that the merely quantitative aspect of desertification sensitivity demon- 
strates a clearer image of the risk state than descriptive approaches. Reliable priority actions can be planned better on basis of risk magnitude knowledge.

Remote sensing, in addition to thematic maps, may supply valuable information concerning the soil and vegetation quality at the general scale. However, for more detailed 5 scales, conventional field observation would be essential. The Geographic Information System (GIS) is a valuable tool to store, retrieve and manipulate the huge amount of data needed to compute and map different quality indices to desertification.

Mathematical modeling should be developed for the operational monitoring of different elements contributing in desertification sensitivity. Multi scale mapping of ESA's 10 are needed to point out the risk magnitude and causes of degradation in problematic areas. Evaluation and validation of the assessment methodology are recommended, they should be a matter of scientific discussions.

The Egyptian territory is susceptible to very high-to-high desertification sensitivity, however the Nile Valley is moderately sensitive because of its vegetation cover. Action

measures are essential for the sustainable agricultural projects located in the desert oases, wadis and interference zone.

\section{References}

ASRT: The soil map of Egypt. Final project report, Cairo, Academy of Scientific Research and Technology, 379 pp., 1982.

The Arab Republic of Egypt (ARE): Monthly weather report, V. 22, reproduced by Information Manufacturing Manufacturing Coroporation, Rocket Center, West Virginia, 14 September 1999, 1979.

Basso, F., Bellotti, A., Bove, E., Faretta, S., Ferrara, A., Mancino, G., Pisante, M., Quaranta, G., and Taberner, M.: Degradation processes in the Agri Basin: evaluating environmental sensitivity to desertification at basin scale, Proceedings International Seminar on "Indicator for Assessing Desertification in the Mediterranean", edited by: Enne, G., D'Angelo, M., and Zanolla, C., Porto Torres, Italy, 18-20 September, Supported by ANPA via Brancati 48, 00144 Roma, 131-145, 1998.
3, 41-85, 2008

Desertification sensitivity

A. Gad and I. Lotfy

Title Page

Abstract Introduction

Conclusions References

Tables

Figures

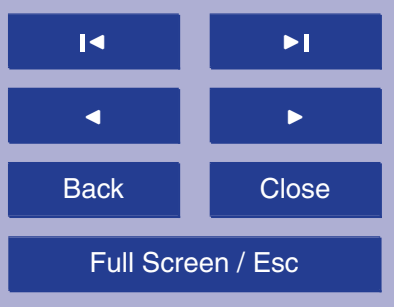

Printer-friendly Version

Interactive Discussion

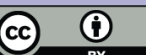


Basso, F., Bove, E., Dumontet, S., Ferrara, A., Pisante, M., Quaranta, G., and Taberner, M.: Evaluating Environmental Sensitivity at the basin scale through the use of Geographic Information Systems and Remote Sensed data: an example covering the Agri basin (southern Italy), Catena, 40, 19-35, 2000.

5 Batterbury, S. P. J. and Warren, A.: Desertification, in: International Encyclopedia of the Social and Behavioral Sciences, edited by: Smelser, N. and Baltes, P., Elsevier Press, 3526-3529, 2001.

Briggs, D., Giordano, A., Cornaert, M., Peter, D., and Maef, J.: CORINE soil erosion risk and important land resources in the southern regions of the European Community, EUR 13233,

$10 \quad$ Luxembourg, 97 pp., 1992.

CONOCO Inc.: Startigraphic Lexicon and explanatory notes to the geological amp of Egypt 1-500,000, edited by: Hermina, M., Klitzsch, E., and List, F. K., Cairo, CONOCO Inc., ISBN 3-927541-09-5,263 pp., 1989.

European Commission (EC): The Medalus project Mediterranean desertification and land use, 15 Manual on key indicators of desertification and mapping environmentally sensitive areas to desertification, edited by: Kosmas, C., Kirkby, M., and Geeson, N., European environment and climate research program - Theme: Land resources and the threat of desertification and soil erosion in Europe (Project ENV4 CT 95 0119), 84 pp., 1999.

Ferrarsa, A., Bellotti, A., Faretta, S., Mancino, G., and Taberner, M.: Identification and assessment of Environmentally Sensitive Areas by Remote Sensing, MEDALUS III 2.6.2., OU Final Report, King's College, London, 2, 397-429, 1999.

Gad, A.: Assessment and mapping of Desertification sensitivity in the western desert oases of Egypt, based on Remote Sensing and GIS, Proceedings of II International Indian Geography Congress, National Association of Geographers, Udaipur, India, 28 Feb-5 March 2008, p. 151, 2008.

Giordano, L., Giordano, F., Grauso, S., lannetta, M., Sciortino, M., Rossi, L., and Bonati, G.: Identification of areas sensitive to desertification in Sicily Region, ftp://ftp.fao.org/agl/ emailconf/lada/lada4_sciortino_maurizio_attachment.doc, 2007.

Glantz, M. H. (Ed.): Desertification: Environmental Degradation in and around Arid Lands, Boulder, Westview Press, 1977.

Kosmas, C., Ferrara, A., Briasouli, H., and Imeson, A.: Methodology for mapping Environmentally Sensitive Areas (ESAs) to Desertification, in: The Medalus project Mediterranean desertification and land use, Manual on key indicators of desertification and mapping envi-

3, 41-85, 2008

Desertification sensitivity

A. Gad and I. Lotfy

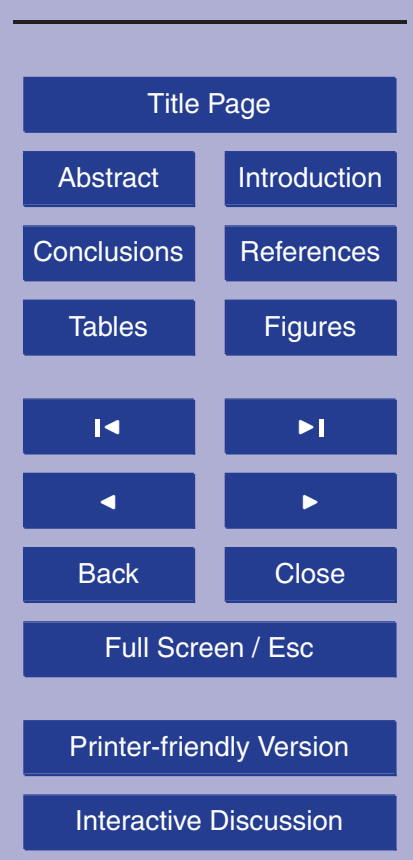


ronmentally sensitive areas to desertification, edited by: Kosmas, C., Kirkby, M., Geeson, N., European Union 18882, ISBN 92-828-6349-2, 31-47, 1999.

Kosmas, C., Poesen, J., and Briasouli, H.: Key indicators of desertification at the ESA a scale, in: Manual on Key Indicators of desertification and Mapping Environmentally Sensitive Areas 5 to Desertification, MEDALUS III Project, King's College, London, 1999.

Nicholson, S. E, Tucker, C. J., and Ba, M. B.: Desertification, Drought and Surface Vegetation: an example from the West African Sahel, B. Am. Meteorol. Soc., 79(5), 815-829, 1998.

OSS: Map of sensitivity to desertification in the Mediterranean basin, Proposal for the methodology for the final map, Rome, Observatory of the Sahara and Sahel (OSS), 2003.

10 Lenney, M. P., Woodcock, C. E., Collins, J. B., and Hamdi, H.: The Status of Agricultural Lands in Egypt: The Use of Multitemporal NDVI Features Derived from Landsat TM, Remote Sens. Environ., 56, 1, 8-20, 1996.

Quintanilla, E. G.: Regional aspects of desertification in Peru, in: Combating Desertification through Integrated Development, UNEP/UNEPCOM International Scientific Symposium, Ab15 stract of Papers, Tashkent, USSR, 114-115, 1981.

Gommes, R., Das, H., Mariani, L., Challinor, A., Tychon, B., Balaghi, R., and Dawod, M. A. A.: Agrometeorological forecasting, Chapter 5, edited by: Rivero Vega, E., Eitzinger, J., Friesland, H., Krüger, R., Otte, U., Trampf, W., Wittich, K.-P., and Zimmermann, K., www. agrometeorology.org/fileadmin/insam/repository/gamp_chapt5.p, 2008.

20 Thornes, J. B.: Mediterranean desertification and the vegetation cover, in: Desertification in a European context: Physical and socio-economic aspects, edited by: Fantechi, R., Peter, D., Balabanis, P., Rubio, J. L., Brussels, Luxembourg, Office for Official Publications of the European Communities, 169-194, 1995.

Tucker, C. J, Dregne, H. E, and Newcomb W. W.: Expansion and Contraction of the Sahara Desert from 1980 to 1990, Science, 253, 299-301, 1991.

Williams, M. A. J.and Balling Jr., R. C.: Interactions of Desertification and Climate, London, Edward Arnold, 1996.

Woodcock, C. E., El-Baz, F., Hamdi, H., et al.: Desertification of Agricultural Lands in Egypt by Remote Sensing, Final Report, 1994.

so Zonn, I. S. (Ed.): USSR/UNEP Projects to Combat Desertification, Moscow Centre of International Projects GKNT, 33, 1981.

World Climatelogical organization (WMO): Climate and Land Degradation, WMO No. 989, ISBN 92-63-10989-3, 2005.

$3,41-85,2008$

Desertification sensitivity

A. Gad and I. Lotfy

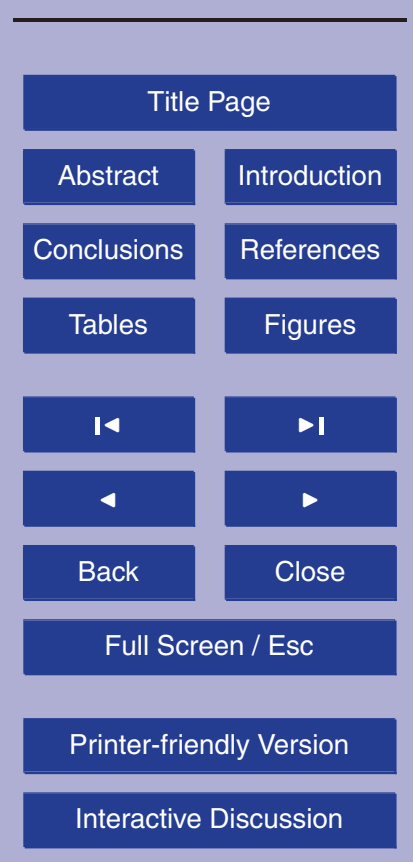

Interactive Discussion

(i) 
$3,41-85,2008$

\section{Desertification} sensitivity

A. Gad and I. Lotfy

Table 1. Classes and assigned weighting index for parent material.

\begin{tabular}{llc}
\hline Class & Description & Score \\
\hline $\begin{array}{l}\text { 1) Coherent: Limestone, dolomite, non-friable } \\
\text { sandstone, hard limestone layer. }\end{array}$ & Good & 1.0 \\
$\begin{array}{l}\text { 2) Moderately coherent: Marine limestone, } \\
\text { friable sandstone }\end{array}$ & Moderate & 1.5 \\
$\begin{array}{l}\text { 3) Soft to friable: Calcareous clay, clay, sandy } \\
\text { formation, alluvium and colluvium }\end{array}$ & Poor & 2 \\
\hline
\end{tabular}

\section{Title Page}

Abstract

Introduction

Conclusions

References

Tables

Figures

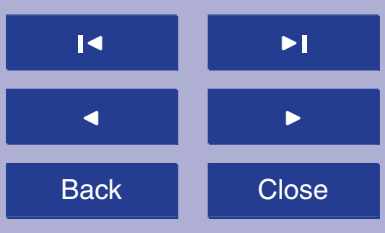

Full Screen / Esc

Printer-friendly Version

Interactive Discussion

Note: In case of deep Aeolian deposits over a rocky parent material, the Aeolian sediments are considered as parent material. 
3, 41-85, 2008

\section{Desertification} sensitivity

A. Gad and I. Lotfy

Table 2. Classes and assigned weighting index for soil depth.

\begin{tabular}{llc}
\hline Class & Description & Score \\
\hline Very deep & Soil thickness is more than $1 \mathrm{~m}$ & 1 \\
Moderately deep & Soil thickness ranges from $<1 \mathrm{~m}$ to $0.5 \mathrm{~m}$ & 1.33 \\
Not deep & Soil thickness ranges from $<0.5 \mathrm{~m}$ to $0.25 \mathrm{~m}$ & 1.66 \\
Very thin & Soil thickness $0.15 \mathrm{~m}$ & 2.00 \\
\hline
\end{tabular}

\begin{tabular}{|c|c|}
\hline \multicolumn{2}{|c|}{ Title Page } \\
\hline Abstract & Introduction \\
\hline Conclusions & References \\
\hline Tables & Figures \\
\hline I4 & \\
\hline 4 & $-\mathbf{I}$ \\
\hline Back & Close \\
\hline Full Screen / Esc \\
\hline Printer-friendly Version
\end{tabular}


$3,41-85,2008$

\section{Desertification} sensitivity

A. Gad and I. Lotfy

Table 3. Classes, and assigned weighting index for soil texture.

\begin{tabular}{llcc}
\hline Texture Classes & Description & \multicolumn{2}{c}{ Score } \\
\hline & & $\begin{array}{c}\text { Areas dominated by } \\
\text { water erosion }\end{array}$ & $\begin{array}{c}\text { Areas dominated by } \\
\text { wind erosion }\end{array}$ \\
\hline Not very light to average & Loamy sand, Sandy loam, Balanced & 1 & 1 \\
Fine to average & Loamy clay, Clayey sand, Sandy clay & 1.33 & 1.66 \\
Fine & Clayey, Clay loam & 1.66 & 2 \\
Coarse & Sandy to very Sandy & 2 & 2 \\
\hline
\end{tabular}

\begin{tabular}{|c|c|}
\hline \multicolumn{2}{|c|}{ Title Page } \\
\hline Abstract & Introduction \\
\hline Conclusions & References \\
\hline Tables & Figures \\
\hline I & \\
\hline 4 & $-\mathbf{I}$ \\
\hline Back & Close \\
\hline Full Screen / Esc \\
\hline Printer-friendly Version
\end{tabular}


3, 41-85, 2008

\section{Desertification} sensitivity

A. Gad and I. Lotfy

Table 4. Classes, and assigned weighting index for Slope gradient.

\begin{tabular}{rlc}
\hline Classes & Description & Score \\
\hline$<6 \%$ & Gentle & 1 \\
$6-18 \%$ & Not very gentle & 1.33 \\
$19-35 \%$ & Abrupt & 1.66 \\
$>35 \%$ & Very abrupt & 2 \\
\hline
\end{tabular}

Title Page

\begin{tabular}{|c|c|}
\hline Abstract & Introduction \\
\hline Conclusions & References \\
\hline Tables & Figures \\
\hline I4 & $-\mathbf{I}$ \\
\hline $\mathbf{4}$ & - \\
\hline Back & Close \\
\hline Full Screen / Esc
\end{tabular}

Printer-friendly Version

Interactive Discussion

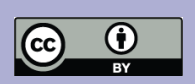


3, 41-85, 2008

\section{Desertification} sensitivity

A. Gad and I. Lotfy

Table 5. Classification of soil quality index.

\begin{tabular}{clc}
\hline Class & Description & Range \\
\hline 1 & High quality & $>1.13$ \\
2 & Moderate quality & 1.13 to 1.45 \\
3 & Low quality & $>1.46$ \\
\hline
\end{tabular}

Title Page

\begin{tabular}{|c|c|}
\hline Abstract & Introduction \\
\hline Conclusions & References \\
\hline Tables & Figures \\
\hline I4 & $\bullet$ \\
\hline 4 & $\triangleright$ \\
\hline Back & Close \\
\hline Full Screen / Esc \\
\hline
\end{tabular}

Printer-friendly Version

Interactive Discussion

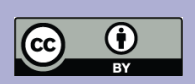


$3,41-85,2008$

\section{Desertification} sensitivity

A. Gad and I. Lotfy

Table 6. Classes, and assigned weighting index for different vegetation parameters.

\begin{tabular}{clccc}
\hline Class & Description & $I_{E p}$ & $I_{D r}$ & $I_{V c}$ \\
\hline 1 & Perennial cultivation & 1 & 1 & 1 \\
2 & Halophytes & 1.33 & 1 & 1.33 \\
3 & Temporal and orchards, mixed with crop land & 1.66 & 1.33 & 1.66 \\
4 & Saharan vegetation $<40 \%$ & 2 & 1.66 & 1 \\
5 & Saharan vegetation $>40 \%$ & 2 & 1 & 1 \\
\hline
\end{tabular}

Title Page

Abstract

Introduction

Conclusions

References

\section{Tables}

Figures

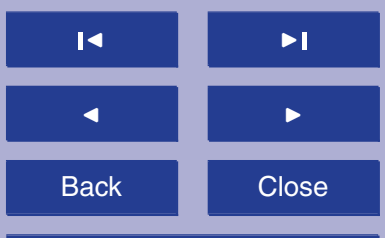

Full Screen / Esc

Printer-friendly Version

Interactive Discussion

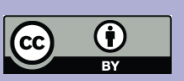


3, 41-85, 2008

\section{Desertification} sensitivity

A. Gad and I. Lotfy

Table 7. Classification of vegetation quality index (VQI).

\begin{tabular}{clc}
\hline Class & Description & Range \\
\hline 1 & Good & $<1.2$ \\
2 & Average & 1.2 to 1.4 \\
3 & Weak & 1.4 to 1.6 \\
4 & Very weak & $>1.6$ \\
\hline
\end{tabular}

Title Page

\begin{tabular}{cc}
\hline Abstract & Introduction \\
\hline Conclusions & References \\
\hline Tables & Figures \\
\hline I4 & \\
\hline 4 & $>$ \\
\hline Back & Close \\
\hline Full Screen / Esc \\
\hline
\end{tabular}

Printer-friendly Version

Interactive Discussion

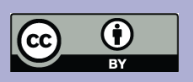


3, 41-85, 2008

\section{Desertification} sensitivity

A. Gad and I. Lotfy

Table 8. Classification of Climatic quality index (CQI).

\begin{tabular}{clcc}
\hline Class number & Climatic zone & P/PET & CQI \\
\hline 1 & Hyper-Arid & $<0.05$ & 2 \\
2 & Arid & $0.05-2.0$ & 1.75 \\
3 & Semi-Arid & $0.20-0.50$ & 1.50 \\
4 & Dry Sub-Humid & $0.50-0.65$ & 1.25 \\
5 & Humid & $>0.65$ & 1 \\
\hline
\end{tabular}

\begin{tabular}{|c|c|}
\hline \multicolumn{2}{|c|}{ Title Page } \\
\hline Abstract & Introduction \\
\hline Conclusions & References \\
\hline Tables & Figures \\
\hline I & \\
\hline 4 & $-\mathbf{I}$ \\
\hline Back & Close \\
\hline Full Screen / Esc \\
\hline Printer-friendly Version
\end{tabular}


3, 41-85, 2008

\section{Desertification} sensitivity

A. Gad and I. Lotfy

Table 9. Ranges and classes of desertification sensitivity index (DSI).

\begin{tabular}{ccl}
\hline Classes & DSI & Description \\
\hline 1 & $>1.2$ & Non affected areas or very low sensitive areas to desertification \\
2 & $1.2<\mathrm{DSI}<1.3$ & Low sensitive areas to desertification \\
3 & $1.3<\mathrm{DSI}<1.4$ & Medium sensitive areas to desertification \\
4 & $1.3>\mathrm{DSI}<1.6$ & Sensitive areas to desertification \\
5 & $\mathrm{DSI}>1.6$ & Very sensitive areas to desertification \\
\hline
\end{tabular}

Title Page

Abstract

Introduction

Conclusions

References

Tables

Figures

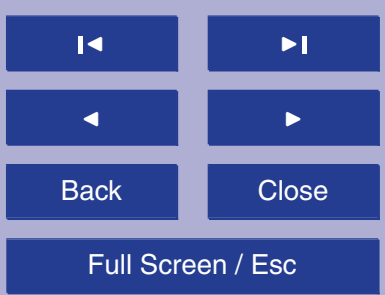

Printer-friendly Version

Interactive Discussion 
3, 41-85, 2008

\section{Desertification} sensitivity

A. Gad and I. Lotfy

Table 10. Nature of parent material classes of Egyptian territory and assigned scores.

\begin{tabular}{lccc}
\hline Class & Score & Area $\left(\mathrm{km}^{2}\right)$ & $\%$ \\
\hline Coherent & 1 & 179616.39 & 18.01 \\
Moderately Coherent & 1.5 & 338890.46 & 33.97 \\
Soft to friable & 2 & 479009.13 & 48.02 \\
\hline Total & - & 997515.98 & 100 \\
\hline
\end{tabular}

Title Page

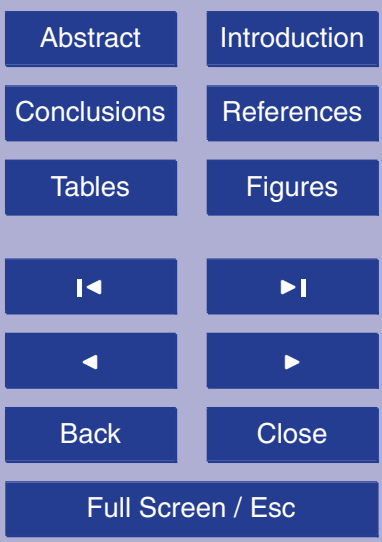

Printer-friendly Version

Interactive Discussion

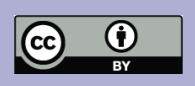


3, 41-85, 2008

\section{Desertification} sensitivity

A. Gad and I. Lotfy

Table 11. Distribution of soil depth classes and assigned scores in the Egyptian territory.

\begin{tabular}{lccc}
\hline Class & Score & Area $\left(\mathrm{km}^{2}\right)$ & $\%$ \\
\hline Very shallow & 1.00 & 441126.17 & 44.22 \\
Shallow & 1.33 & 265446.21 & 26.61 \\
Deep & 1.66 & 47103.87 & 4.72 \\
Very deep & 2.00 & 243839.73 & 24.44 \\
\hline Total & - & 997515.98 & 100 \\
\hline
\end{tabular}

\begin{tabular}{|c|c|}
\hline \multicolumn{2}{|c|}{ Title Page } \\
\hline Abstract & Introduction \\
\hline Conclusions & References \\
\hline Tables & Figures \\
\hline I & \\
\hline 4 & $-\mathbf{I}$ \\
\hline Back & Close \\
\hline Full Screen / Esc \\
\hline Printer-friendly Version
\end{tabular}


3, 41-85, 2008

\section{Desertification} sensitivity

A. Gad and I. Lotfy

Table 12. Distribution of soil texture classes and assigned scores in the Egyptian territory.

\begin{tabular}{llccc}
\hline Class & Description & Score & Area $\left(\mathrm{km}^{2}\right)$ & $\%$ \\
\hline Very light to average & Loamy, Sandy, Sandy-loam, balanced & 1.00 & 167425.65 & 16.78 \\
Fine to average & Loamy clay, Clayey-sand, Sandy clay & 1.33 & 16994.83 & 1.70 \\
Average & Clay, Clay-Loam & 1.66 & 82299.74 & 8.25 \\
Coarse & Sandy to Very sandy & 2.00 & 730795.76 & 73.26 \\
\hline Total & & - & 997515.98 & 100 \\
\hline
\end{tabular}

\begin{tabular}{|c|c|}
\hline \multicolumn{2}{|c|}{ Title Page } \\
\hline Abstract & Introduction \\
\hline Conclusions & References \\
\hline Tables & Figures \\
\hline I & \\
\hline 4 & $-\mathbf{I}$ \\
\hline Back & Close \\
\hline Full Screen / Esc \\
\hline Printer-friendly Version
\end{tabular}


3, 41-85, 2008

\section{Desertification} sensitivity

A. Gad and I. Lotfy

Table 13. Distribution of slope classes and assigned scores in the Egyptian territory.

\begin{tabular}{lccc}
\hline Class & Score & Area $\left(\mathrm{km}^{2}\right)$ & $\%$ \\
\hline Gentle & 1.00 & 57134.61 & 5.73 \\
Not very gentle & 1.33 & 217333.01 & 21.79 \\
Abrupt & 1.66 & 276935.89 & 27.76 \\
Very abrupt & 2.00 & 446043.05 & 44.72 \\
\hline Total & - & 997515.98 & 100 \\
\hline
\end{tabular}

Title Page

\begin{tabular}{|c|c|}
\hline Abstract & Introduction \\
\hline Conclusions & References \\
\hline Tables & Figures \\
\hline I4 & $\bullet$ \\
\hline 4 & $\triangleright$ \\
\hline Back & Close \\
\hline Full Screen / Esc \\
\hline
\end{tabular}

Printer-friendly Version

Interactive Discussion 
$3,41-85,2008$

\section{Desertification} sensitivity

A. Gad and I. Lotfy

Table 14. Areas of different categories of Soil Quality Index (SQI) classes.

\begin{tabular}{lccc}
\hline Class & Score & Area $\left(\mathrm{km}^{2}\right)$ & $\%$ \\
\hline Very Low Quality & $>1.6$ & 646757.90 & 64.84 \\
Low Quality & $1.4-1.6$ & 131656.25 & 13.20 \\
Moderate Quality & $1.2-1.4$ & 219032.41 & 21.96 \\
\hline Total & - & 997515.98 & 100 \\
\hline
\end{tabular}

Title Page

Abstract

Introduction

Conclusions

References

Tables

Figures

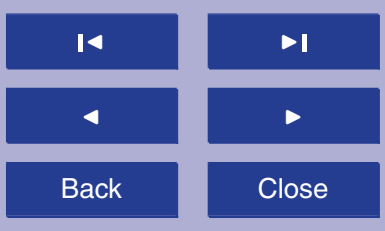

Full Screen / Esc

Printer-friendly Version

Interactive Discussion

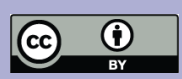


$3,41-85,2008$

\section{Desertification} sensitivity

A. Gad and I. Lotfy

Table 15. Vegetation cover classes and assigned scores for different elements.

\begin{tabular}{lrccc}
\hline Class & $\begin{array}{r}\text { Area } \\
\left(\mathrm{km}^{2}\right)\end{array}$ & $\begin{array}{r}\text { Drought resistance } \\
\text { scores }\end{array}$ & $\begin{array}{r}\text { Erosion protection } \\
\text { scores }\end{array}$ & $\begin{array}{c}\text { Vegetation cover } \\
\text { scores }\end{array}$ \\
\hline Cultivated Land & 45536.36 & 1.00 & 1.00 & 1.00 \\
Halophytes & 13851.56 & 1.00 & 1.33 & 1.33 \\
Orchards Mixed with crop land & 9388.44 & 1.33 & 1.66 & 2 \\
Saharan Vegetation $<40 \%$ & 904024.57 & 1.66 & 2 & 2 \\
Saharan Vegetation $>40 \%$ & 24645.63 & 2.00 & & \\
\hline Total & 997515.98 & & & \\
\hline
\end{tabular}

\begin{tabular}{|c|c|}
\hline \multicolumn{2}{|c|}{ Title Page } \\
\hline Abstract & Introduction \\
\hline Conclusions & References \\
\hline Tables & Figures \\
\hline I4 & \\
\hline 4 & $-\mathbf{I}$ \\
\hline Back & Close \\
\hline Full Screen / Esc \\
\hline Printer-friendly Version
\end{tabular}


$3,41-85,2008$

\section{Desertification} sensitivity

A. Gad and I. Lotfy

Table 16. Areas of different vegetation quality index classes.

\begin{tabular}{lcrr}
\hline Class & Score & Area $\left(\mathrm{km}^{2}\right)$ & $\%$ \\
\hline Good & $<1.2$ & 34974.9 & 3.51 \\
Average & $1.2-1.4$ & 13851.56 & 1.39 \\
Week & $1.4-1.6$ & 8142.71 & 0.82 \\
Very week & $>1.6$ & 940477.39 & 94.29 \\
\hline Total & - & 997515.98 & 100 \\
\hline
\end{tabular}

Title Page

\begin{tabular}{cc|}
\hline Abstract & Introduction \\
\hline Conclusions & References \\
\hline Tables & Figures \\
\hline I4 & \\
\hline 4 & $>$ \\
\hline Back & Close \\
\hline Full Screen / Esc
\end{tabular}

Printer-friendly Version

Interactive Discussion

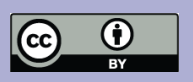


$3,41-85,2008$

\section{Desertification} sensitivity

A. Gad and I. Lotfy

Table 17. Areas of different climatic quality index classes.

\begin{tabular}{lcc}
\hline Class & Area $\left(\mathrm{km}^{2}\right)$ & $\%$ \\
\hline Hyper-arid & 890881.52 & 89.31 \\
Arid & 106634.45 & 10.69 \\
\hline Total & 997515.98 & 100 \\
\hline
\end{tabular}

Title Page

\begin{tabular}{|c|c|}
\hline Abstract & Introduction \\
\hline Conclusions & References \\
\hline Tables & Figures \\
\hline $\mathbf{I}$ & \\
\hline 4 & $>\mathbf{I}$ \\
\hline Back & Close \\
\hline Full Screen / Esc
\end{tabular}

Printer-friendly Version

Interactive Discussion

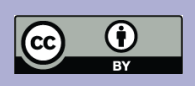


3, 41-85, 2008

\section{Desertification} sensitivity

A. Gad and I. Lotfy

Table 18. Occurrence of Environmentally sensitive areas (ESA's).

\begin{tabular}{lcrr}
\hline Class & Score & Area $\left(\mathrm{km}^{2}\right)$ & $\%$ \\
\hline Non affected or very low sensitive areas & $0.01-1.2$ & 798.01 & 0.08 \\
Low sensitive areas & $1.3-1.4$ & 11072.43 & 1.11 \\
Moderately sensitive areas & $1.4-1.5$ & 41396.91 & 4.15 \\
Sensitive areas & $1.5-1.6$ & 202196.49 & 20.27 \\
Very sensitive areas & $1.7-1.8$ & 742052.14 & 74.39 \\
\hline Total & - & 997515.98 & 100 \\
\hline
\end{tabular}

Title Page

Abstract

Introduction

Conclusions

References

Tables

Figures

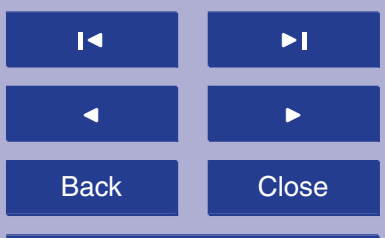

Full Screen / Esc

Printer-friendly Version

Interactive Discussion 
3, 41-85, 2008

\section{Desertification} sensitivity

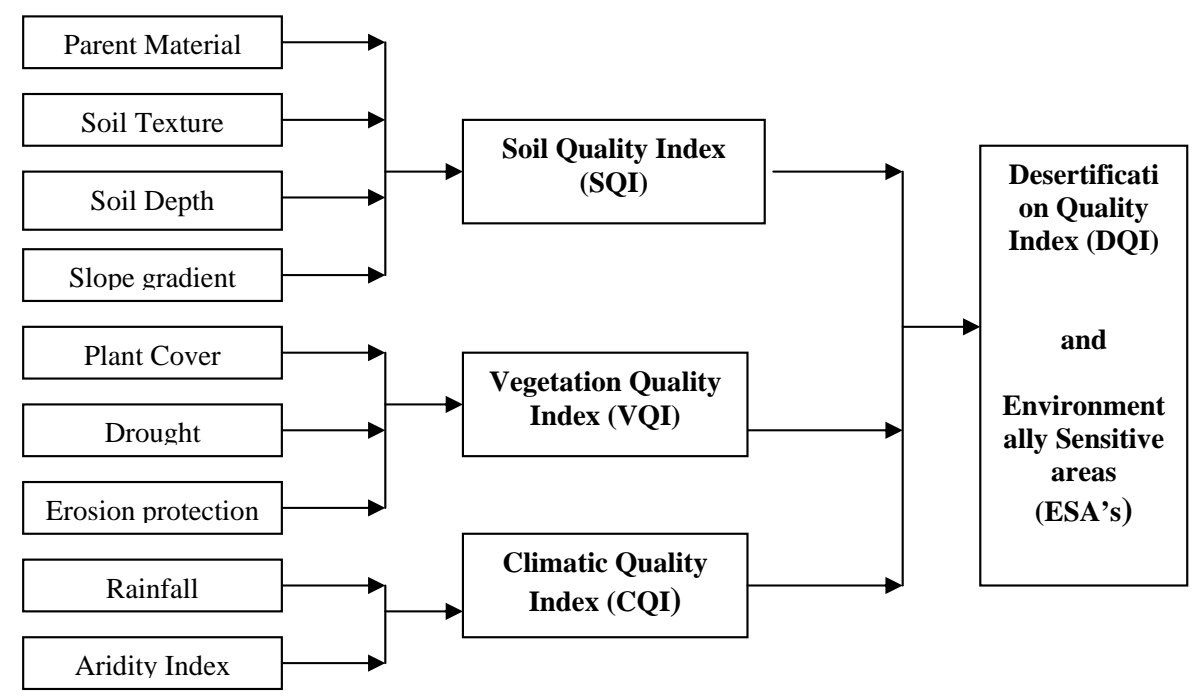

A. Gad and I. Lotfy

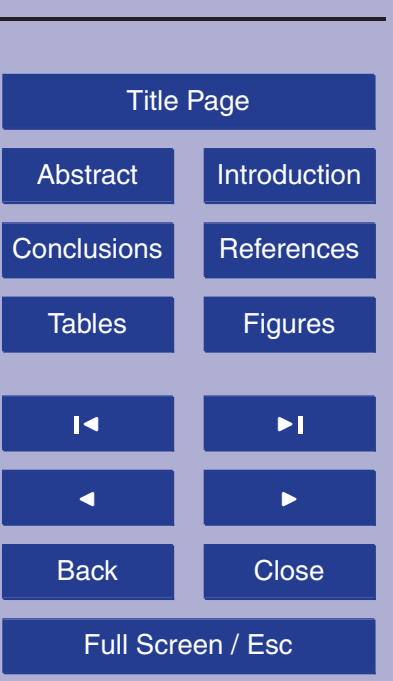

Fig. 1. Flow chart of mapping Environmentally Sensitive Areas (ESA's).

Printer-friendly Version

Interactive Discussion

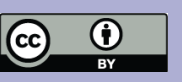


$3,41-85,2008$

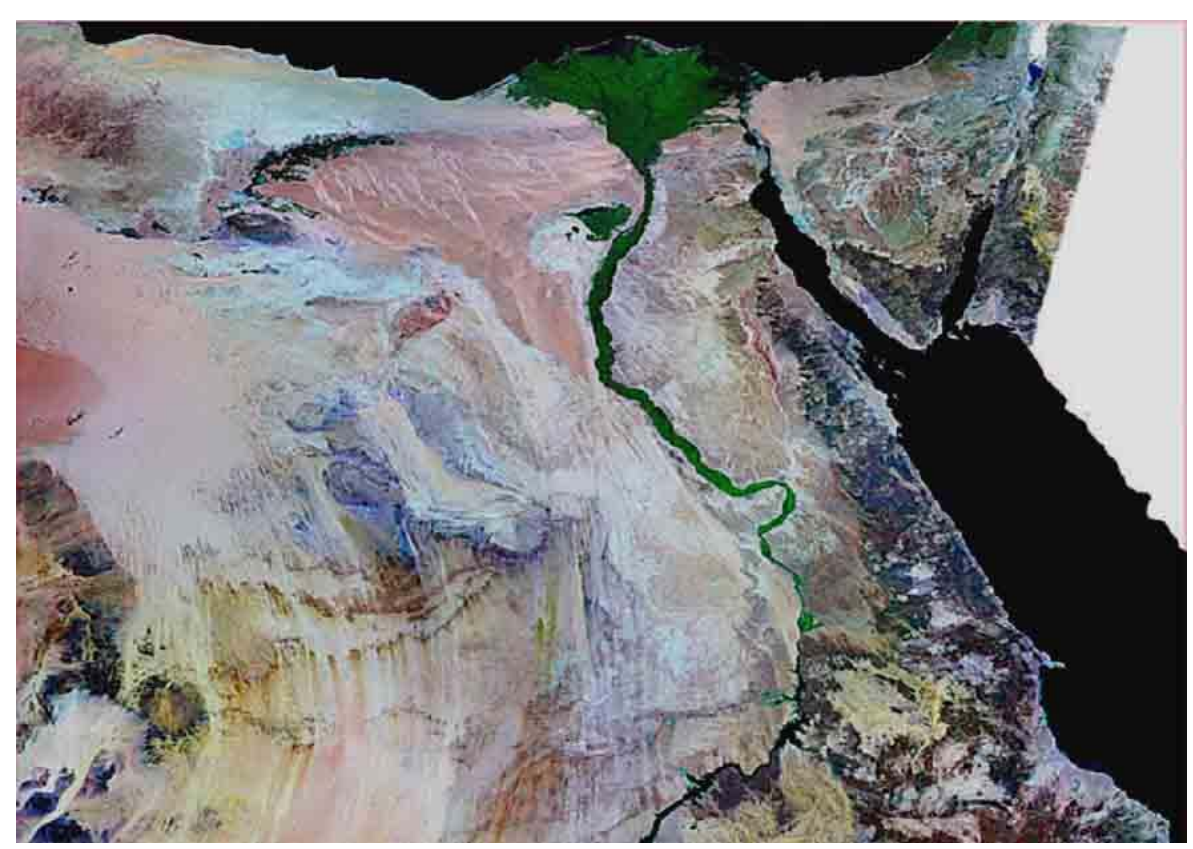

Desertification sensitivity

A. Gad and I. Lotfy

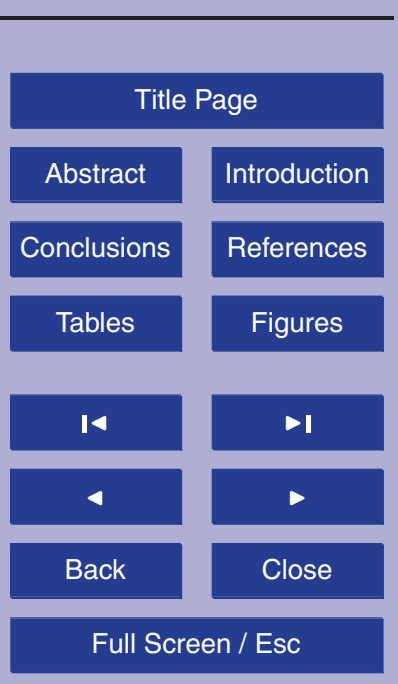

Fig. 2. TM satellite images mosaic covering Egypt.

Printer-friendly Version

Interactive Discussion

(a) (1) 
3, 41-85, 2008

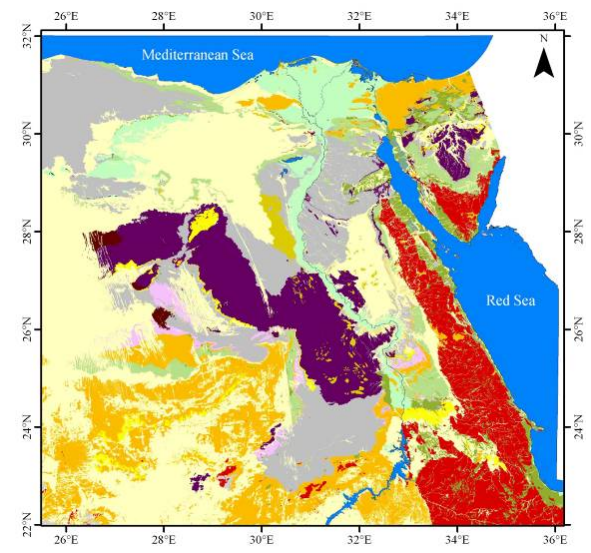

Coherent Hard Crystalline Rock

Coherent Hard limestone

Coherent Non Friable Sandstone Friable Sandy Formation

Friable Sandy Formation and calcareous clay

Friable Sandy Formation and colluvium Friable colluvium

Moderately Coherent Crystalline Rock

Moderately Coherent Friable Sandstone

Moderately Coherent Friable gypsum

Moderately Coherent Limestone \& Friable Sandstone

Moderately Coherent Limestone and Marl

Moderately Coherent friable Sandstone \& conglomera

Moderately Coherent friable sandstone, alluvium

Soft Alluvium

Soft Clay and Sandy Formation

Soft to friable calcarus clay

Fig. 3. Nature of parent material in the Egyptian territory.

\section{Desertification} sensitivity

A. Gad and I. Lotfy

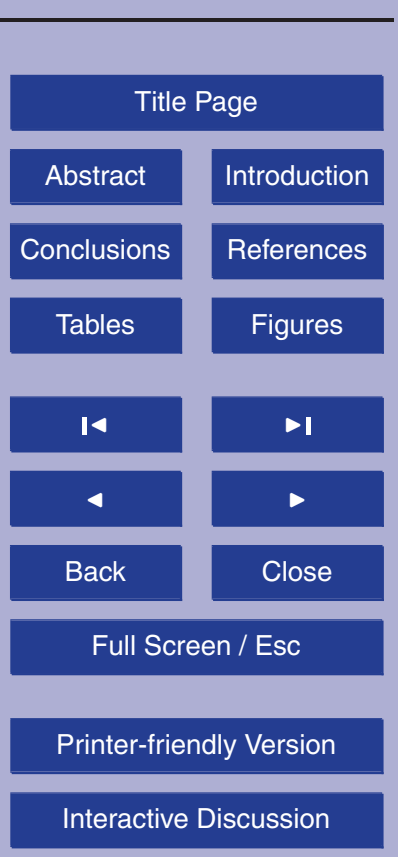

(). (1) 
3, 41-85, 2008

\section{Desertification} sensitivity

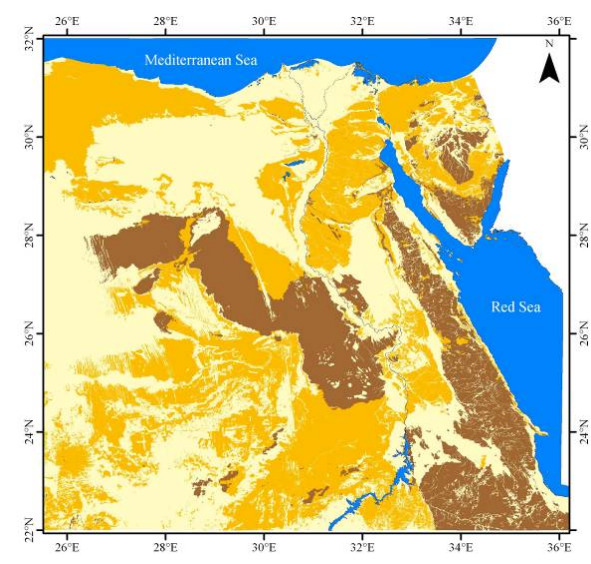

\section{Legend}

Water bodies (Score: 0 )

Coherent (Score: 1)

Moderately coherent (Score: 1.5)

Soft to friable (Score: 2)

Fig. 4. Re-categorization of parent material natures in the Egyptian territory.
A. Gad and I. Lotfy

\begin{tabular}{|c|c|}
\hline \multicolumn{2}{|c|}{ Title Page } \\
\hline Abstract & Introduction \\
\hline Conclusions & References \\
\hline Tables & Figures \\
\hline & \\
\hline I & $\bullet$ \\
\hline 4 & $\triangleright$ \\
\hline Back & Close \\
\hline Full Screen / Esc
\end{tabular}

Printer-friendly Version

Interactive Discussion 
3, 41-85, 2008

Desertification sensitivity

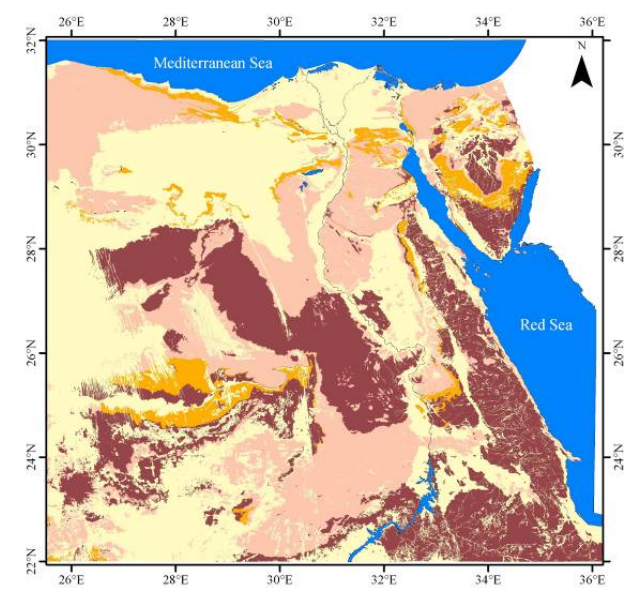

\section{Legend}

Water bodies (Score: 0 )

Very shallow (Scoer: 1)

Shallow (Scoer: 1.33)

Deep (Scoer: 1.66)

Very deep (Scoer: 2)

Fig. 5. Categories of soil depth as contributing in soil quality index.

A. Gad and I. Lotfy

\begin{tabular}{|c|c|}
\hline \multicolumn{2}{|c|}{ Title Page } \\
\hline Abstract & Introduction \\
\hline Conclusions & References \\
\hline Tables & Figures \\
\hline I4 & \\
\hline 4 & $\bullet$ \\
\hline Back & Close \\
\hline Full Screen / Esc
\end{tabular}

Printer-friendly Version

Interactive Discussion 
$3,41-85,2008$

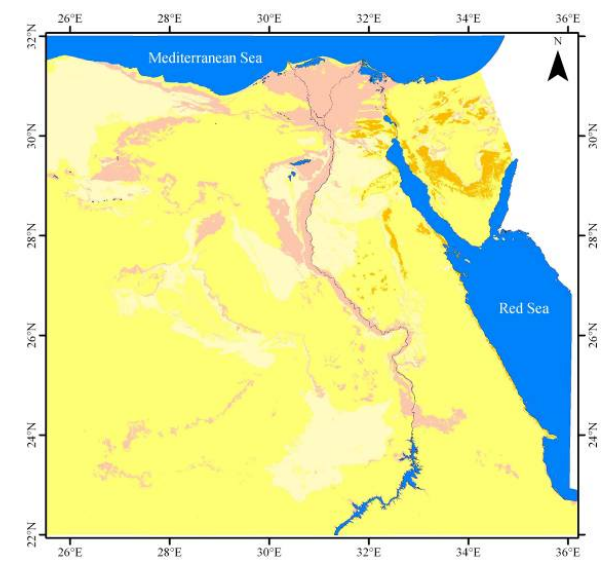

\section{Legend}

Water bodies (Score: 0 ) Very light to average (Score:1) Fine to average (Score:1.33)

Average (Score:1.66)

Coarse (Score: 2 )

Fig. 6. Categories of soil texture as contributing in soil quality index.

\section{Desertification} sensitivity

A. Gad and I. Lotfy

\begin{tabular}{|c|c|}
\hline \multicolumn{2}{|c|}{ Title Page } \\
\hline Abstract & Introduction \\
\hline Conclusions & References \\
\hline Tables & Figures \\
\hline I4 & \\
\hline 4 & $\bullet$ \\
\hline Back & Close \\
\hline Full Screen / Esc
\end{tabular}

Printer-friendly Version

Interactive Discussion 
3, 41-85, 2008

\section{Desertification} sensitivity

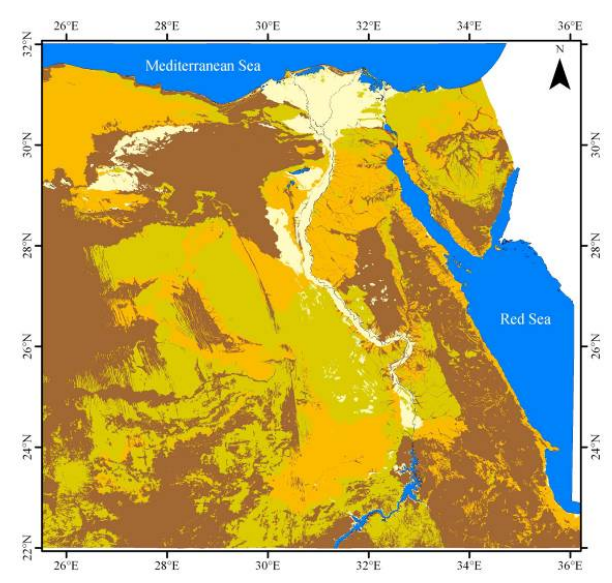

\section{Legend}

Water bodies (Score: 0 )

Gentle (Score: 1)

Not very gentle (Score: 1.33)

Abrupt (Score: 1.66)

very abrupt (Score: 2 )
A. Gad and I. Lotfy

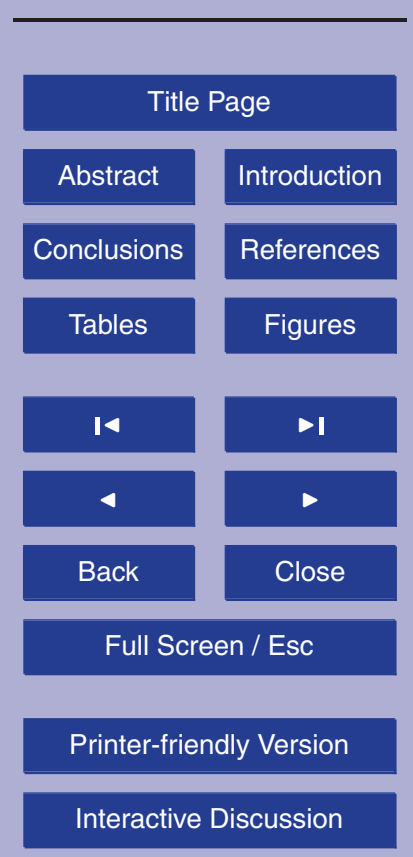

Fig. 7. Categories of slope gradient as contributing in soil quality index.

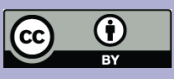


3, 41-85, 2008

\section{Desertification} sensitivity

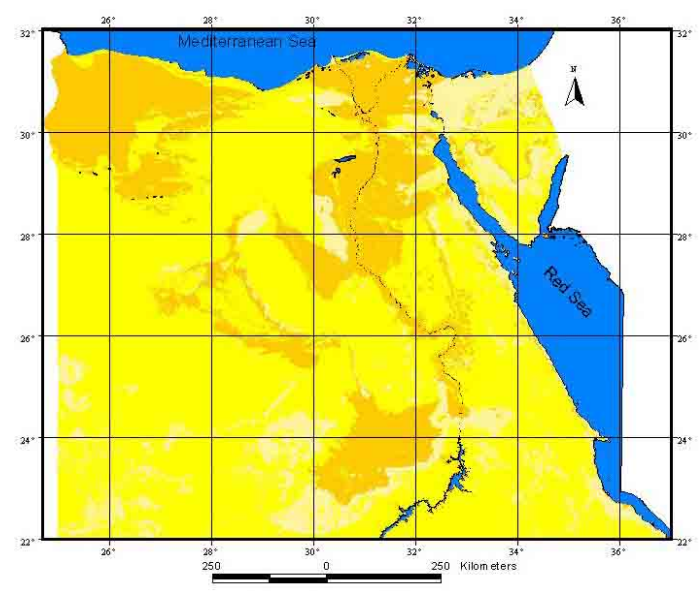

\section{Legend}

\begin{tabular}{|l|l|}
\hline Description & Score \\
\hline Moder ate Quality & $1.2-1.4$ \\
Low Quality & $1.4-1.6$ \\
Very Low Quality & $>1.6$ \\
\hline
\end{tabular}

Fig. 8. Soil quality Index map (SQI).

A. Gad and I. Lotfy

\begin{tabular}{|c|c|}
\hline \multicolumn{2}{|c|}{ Title Page } \\
\hline Abstract & Introduction \\
\hline Conclusions & References \\
\hline Tables & Figures \\
\hline I4 & \\
\hline 4 & $\bullet$ \\
\hline Back & Close \\
\hline Full Screen / Esc
\end{tabular}

Printer-friendly Version

Interactive Discussion 
3, 41-85, 2008

\section{Desertification sensitivity}

A. Gad and I. Lotfy

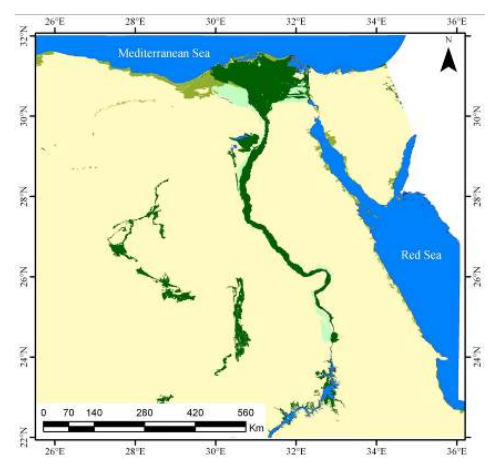

\section{Legend}

Water bodies (Score: 0 )

Perennaial cultivation (Score: 1)

Halophytes (Score: 1)

Orchards Mixed with crop land (Score: 1.33)

Saharian Vegetation $<40 \%$ (Score: 1.66 )

Saharian Vegetation $>40 \%$ (Score: 2 )

Title Page

\begin{tabular}{|c|c|}
\hline Abstract & Introduction \\
\hline Conclusions & References \\
\hline Tables & Figures \\
\hline I4 & $\triangleright \mathbf{I}$ \\
\hline 4 & $\triangleright$ \\
\hline Back & Close \\
\hline Full Screen / Esc \\
\hline
\end{tabular}

Printer-friendly Version

Interactive Discussion 
$3,41-85,2008$

\section{Desertification sensitivity}

A. Gad and I. Lotfy

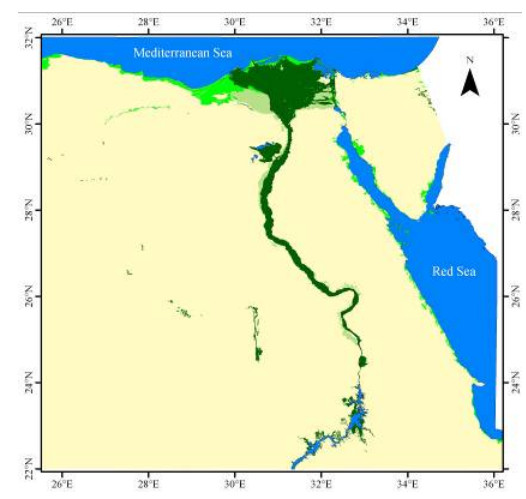

\section{Legend}

Water

Good (Score: <1.2)

Average (Score: 1.2-1.4)

Weak (Score: 1.4-1.6)

Very Weak (Score: > 1.6)

Fig. 10. Vegetation Quality Index (VQI), as contributing in desertification sensitivity.

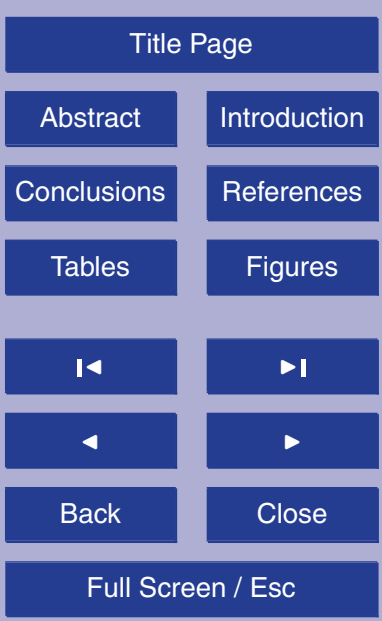

Printer-friendly Version

Interactive Discussion

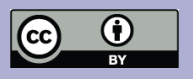


$3,41-85,2008$

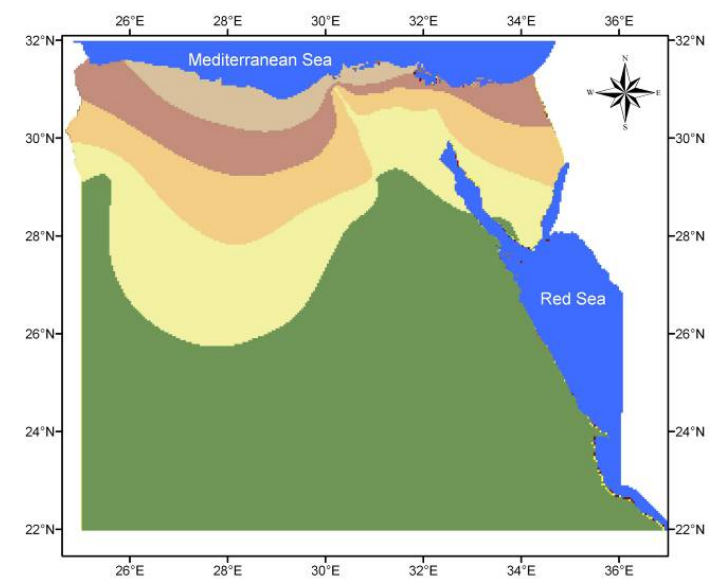

Fig. 11. Average annual precipitation in Egypt, on basis of meteorological data.

\section{Desertification} sensitivity

A. Gad and I. Lotfy

\section{Precepetation $(\mathrm{mm})$}

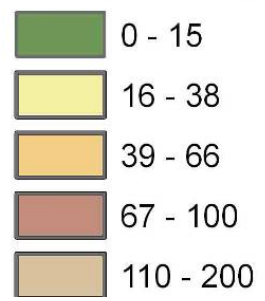

Abstract

Conclusions

Tables

\section{Figures}

\begin{tabular}{|c|c|}
\hline 14 & $>1$ \\
\hline Back & Close \\
\hline Full Screen / Esc \\
\hline
\end{tabular}

Printer-friendly Version

Interactive Discussion 
$3,41-85,2008$
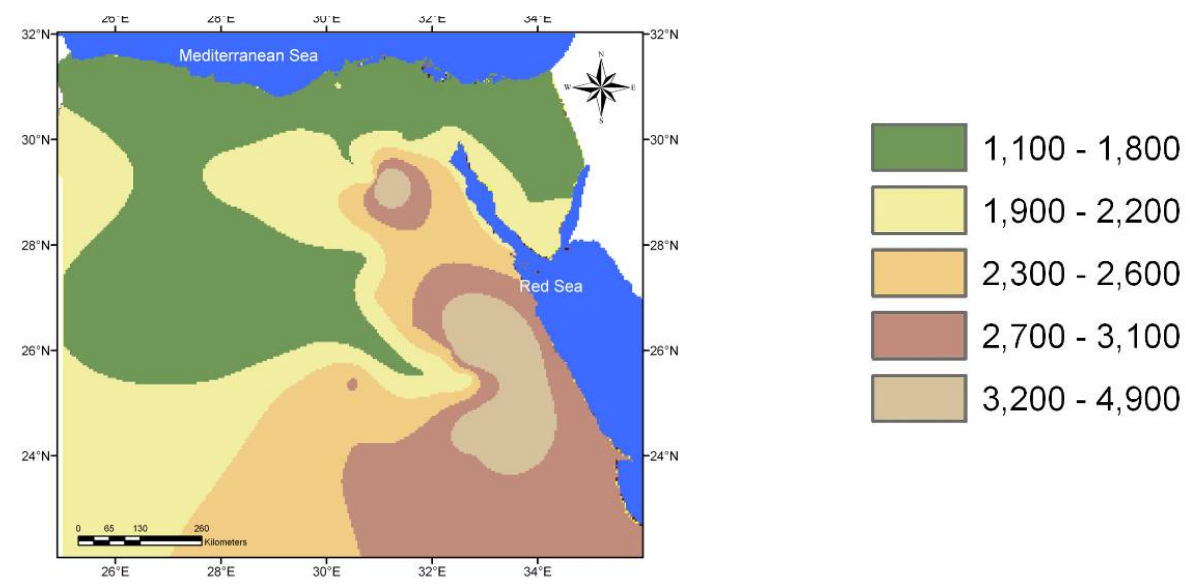

Fig. 12. Average annual Potential evap-transpiration in Egypt, on basis of meteorological data.
Desertification sensitivity

A. Gad and I. Lotfy

\begin{tabular}{|c|c|}
\hline \multicolumn{2}{|c|}{ Title Page } \\
\hline Abstract & Introduction \\
\hline Conclusions & References \\
\hline Tables & Figures \\
\hline & \\
\hline I4 & \multicolumn{1}{|c|}{} \\
\hline 4 & Close \\
\hline Back & Full Screen / Esc \\
\hline
\end{tabular}

Printer-friendly Version

Interactive Discussion 
3, 41-85, 2008

\section{Desertification} sensitivity

A. Gad and I. Lotfy

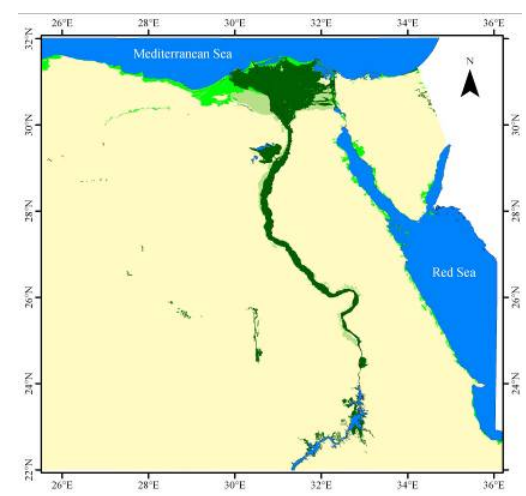

\section{Legend}

Water

Good (Score: <1.2)

Average (Score: 1.2-1.4)

Weak (Score: 1.4-1.6)

Very Weak (Score: $>1.6$ )

Fig. 13. Climatic sensitivity in Egypt, on basis of meteorological data.

\begin{tabular}{|c|c|}
\hline \multicolumn{2}{|c|}{ Title Page } \\
\hline Abstract & Introduction \\
\hline Conclusions & References \\
\hline Tables & Figures \\
\hline I4 & \\
\hline 4 & $\bullet$ \\
\hline Back & Close \\
\hline Full Screen / Esc
\end{tabular}

Printer-friendly Version

Interactive Discussion

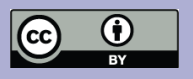


3, 41-85, 2008

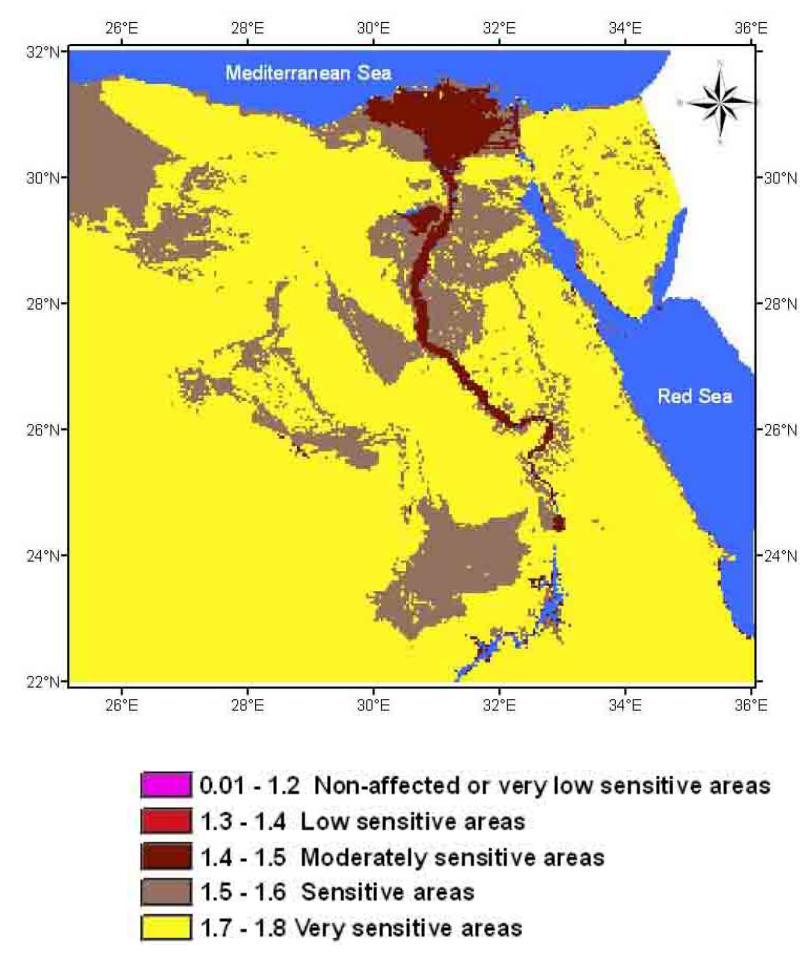

\section{Desertification} sensitivity

A. Gad and I. Lotfy

\begin{tabular}{|c|c|}
\hline \multicolumn{2}{|c|}{ Title Page } \\
\hline Abstract & Introduction \\
\hline Conclusions & References \\
\hline Tables & Figures \\
\hline I4 & \\
\hline 4 & $\bullet$ \\
\hline Back & Close \\
\hline Full Screen / Esc
\end{tabular}

Fig. 14. Environmentally sensitive areas (ESA's) for desertification in Egypt.

Printer-friendly Version

Interactive Discussion

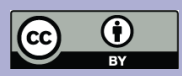

